\title{
Program Literasi Digital bagi Anak-Anak Kampung Wonopuro, Dusun Sidowayah, Kabupaten Ponorogo
}

\author{
Digital Literacy Program for Children in Kampung Wonopuro, \\ Dusun Sidowayah, Ponorogo Regency
}

\author{
Endang Sri Maruti $^{1 凶}$, Binti Isticomah ${ }^{2}$, Galuh Mei Yustiwa ${ }^{3}$, \\ Ulifa Khoiru ${ }^{4}$, \& Nur Huda ${ }^{5}$ \\ 12345 Program Studi Pendidikan Guru Sekolah Dasar, Fakultas Keguruan \& \\ Ilmu Pendidikan, Universitas PGRI Madiun, Indonesia \\ endang@unipma.ac.id
}

Article history:

Submitted: 14 June 2021

Accepted: 8 July 2021

Published: 12 July 2021

\begin{abstract}
Children in their education are among those are most affected during the Covid-19 pandemic because they have to study at home online while teachers have never held home visits to monitor student learning processes directly. As a result, many children cannot learn optimally. This program aims to help children to improve their digital literacy skills and also make it easier for parents to guide and monitor their children's activities. For this reason, this program is carried out as an effort for Digital Literacy for isolated village children in Kampung Wonopuro, Dusun Sidowayah, Ponorogo Regency of East Java Province, so that they can continue to live life like children in other advanced villages. The program has resulted that it can improve digital literacy for the participating children. From the social side, children's enthusiasm for learning to develop their potential and achievements in the midst of the current pandemic is highly discoverable; while from a psychological point of view, it can help increase the learning motivation of the children in Kampung Wonopuro.
\end{abstract}

Keywords: digital literacy; Kampung Wonopuro; learning assistance; Let's Read application; Sidowayah Ponorogo

Abstrak: Anak-anak dalam pendidikannya termasuk yang paling terdampak di masa pandemi Covid-19 karena harus belajar di rumah secara online sedangkan guru tidak pernah melakukan kunjungan rumah untuk memantau proses belajar siswa secara langsung. Akibatnya banyak anak yang tidak bisa belajar secara maksimal. Program ini bertujuan untuk membantu anak-anak meningkatkan kemampuan literasi digitalnya dan juga memudahkan orang tua dalam membimbing dan memantau aktivitas anaknya. Untuk itu, program ini dilakukan sebagai upaya Literasi Digital bagi anak-anak desa terpencil di Kampung Wonopuro, Dusun Sidowayah, Kabupaten Ponorogo Provinsi Jawa Timur, agar mereka dapat terus menjalani kehidupan seperti anak-anak di desa maju lainnya. Program tersebut telah menghasilkan dapat meningkatkan literasi digital bagi anak-anak peserta. Dari sisi sosial, semangat belajar anak untuk mengembangkan potensi dan prestasinya di tengah pandemi saat ini sangat terlihat; sedangkan dari segi psikologis dapat membantu meningkatkan motivasi belajar anak-anak di Kampung Wonopuro.

Kata kunci: aplikasi Let's Read; Kampung Wonopuro; literasi digital; pendampingan belajar; Sidowayah Ponorogo 


\section{Pendahuluan}

Kampung Wonopuro merupakan lingkungan yang terletak di bukit Rajakwesi, Dukuh Sidowayah RT.11 RW.03 Desa Sidoharjo, Kecamatan Jambon, Kabupaten Ponorogo, Provinsi Jawa Timur. Terlepas dari Dukuh Sidowayah, Desa Sidoharjo, dan desa tetangga yaitu Desa Krebet merupakan daerah yang menjadi menjadi wilayah dampingan atau kerja sosial karena keberadaan fenomena "kampung idiot" (Fitriawan et al, 2020), tim pengabdi lebih memfokuskan pada aspek lain di Kampung Wonopuro. Kampung ini dikategorikan sebagai wilayah terisolir karena untuk menuju wilayah tersebut hanya ada satu jalan yang berupa jalan makadam selebar 1-2 meter.

Tercatat jumlah penduduk Kampung Wonopuro sebanyak 154 jiwa, dengan 53 KK dan 27 rumah. Dari populasi tersebut, terdapat 23 anak usia sekolah: sepuluh siswa sedang mengenyam pendidikan di tingkat SMP dengan rincian delapan anak kelas 9 dan dua anak di kelas 7; delapan siswa lainnya menempuh pendidikan Sekolah Dasar; serta lima lainnya tidak atau belum bersekolah. Pada dasarnya anak-anak tersebut mempunyai kreativitas dan keterampilan yang masih bisa diasah dan dikembangkan, tetapi tidak ada pendamping yang membantu mengarahkan anak-anak ke bakat dan minat yang mereka inginkan, sehingga, anak-anak tersebut menjadi spesial dan kurang berkembang. Memasuki era pandemi Covid-19, anak-anak di desa ini semakin tertinggal dalam pendidikan karena harus belajar di rumah secara dalam jaringan (daring), dan guru sama sekali tidak pernah mengadakan kegiatan kunjung rumah untuk memantau proses belajar siswa secara langsung. Akibatnya, banyak anak yang tidak bisa belajar secara maksimal.

Kurangnya peran keluarga dan lingkungan baik sekolah maupun masyarakat sekitar menjadi penyubur masalah bagi anak-anak khususnya terkait masalah literasi. Agar dapat berpartisipasi di tengah arus globalisasi dan regionalisasi pada abad ke-21, pendidikan harus berfokus pada literasi dasar, kompetensi dan kualitas karakter (Samsiyah, 2019). Literasi sebagai dasar dalam kemampuan memahami secara global. Kurangnya partisipasi lingkungan dalam mendukung literasi mengakibatkan anak-anak di desa tersebut masih banyak yang tidak meneruskan sekolah lanjut dan alhasil mereka belajar apa yang dilakukan orang tuanya seperti berkebun. Mereka tidak mempunyai pekerjaan tetap hanya mengandalkan lahan pertanian tanah dari pemerintah.

Berdasarkan permasalahan di atas, program ini bertujuan membantu anak-anak untuk meningkatkan kemampuan literasi digital dan juga memudahkan orang tua untuk memandu sekaligus memonitor kegiatan anak-anak. Untuk itulah program ini dilakukan sebagai upaya edukasi dan literasi digital bagi anak-anak kampung terisolir supaya tetap dapat menjalani kehidupan seperti layaknya anak-anak pada umumnya.

Literasi ditujukan agar anak percaya diri, lancar dan paham dalam keterampilan membaca dan menulis (Abidin, 2015). Literasi modern adalah praktik membaca, menulis, dan berbicara dalam berbagai lintas budaya dan konteks lintas nasional (Street, 1993). Ciri khas dari studi ini adalah deskripsi penggunaan aktual dan konsepsi literasi secara spesifik pada konteks budaya (Hull \& Hernandez, 2008). Heath (2011) menggaungkan adanya literasi berbasis ekologi atau lingkungan daripada hanya mengandalkan belajar di sekolah, dan sekarang lebih dikenal dengan istilah ekoliterasi. Literasi digital merupakan kemampuan individu menggunakan teknologi digital dan alat komunikasi untuk mengakses, mengelola, mengintegrasi, menganalisis, dan mengevaluasi informasi (Harras, 2011). 
Dalam menyongsong era society 5.0 salah satu terobosan dalam dunia pendidikan adalah pengunaan literasi digital untuk menunjang pengetahuan dan aktivitas membaca siswa usia sekolah dasar khususnya. Literasi digital merupakan kegiatan literasi dengan memanfaatkan media sosial seperti handphone atau android yang berisi bacaan menarik sesuai perkembangan usia anak. Salah satu aplikasi yang bisa dimanfaatkan adalah Let's Read. Aplikasi ini memiliki fitur bacaan yang lengkap dan mudah diinstal serta tidak perlu membawa buku-buku bacaan yang harus dipahami isinya dengan mencatat sebagai ringkasannya (Samsiyah, Suharto and Maruti, 2019). Ratusan cerita bergambar sesuai dengan perkembangan siswa sekolah dasar dapat dibaca, diunduh, disebarkan dan diterjemahkan secara bebas melalui aplikasi Android. Selain itu untuk mendapatkan informasi tentang buku unggulan dan buku-buku tingkat level untuk diajarkan di kelas yang sesuai dengan perkembangan usia dapat membuka instragam Let's Read dan facebook Let's Read (Ermerawati, 2019).

Let's Read merupakan perpustakaan digital yang memiliki koleksi buku cerita anak dengan berbagai tema, mulai dari cerita fiksi, fabel, eksposisi, eksplanasi, dan lain sebagainya. Aplikasi ini diprakarsai oleh Books For Asia dengan tujuan untuk membudayakan kegiatan membaca pada anak sejak usia dini (Putri, 2021). Program ini pertama kali digulirkan tahun 1954 oleh The Asia Foundation dengan cara mendonasikan buku cerita anak. Untuk menghasilkan buku cerita anak yang bermutu The Asia Foundation merangkul komunitas atau organisasi yang bergerak di bidang literasi dan menjembatani para penulis, editor, ilustrator, desain, organisasi, dan translator di beberapa negara Asia. Pada tahun 2017 program donasi buku ini meraih U.S. Library of Congress Literacy Awards atas inovasi dalam promosi literasi.

Latar belakang Kampung Wonopuro yang sedemikian rupa, serta profil aplikasi Let's Read yang diharapkan dapat menjadi salah satu solusi pembelajaran, khususnya literasi digital untuk anak-anak, menjadi motivasi yang digunakan oleh tim pengabdi.

\section{Metode Pengabdian}

Pelaksanaan program literasi melalui aplikasi Let's Read bagi anak-anak Kampung Wonopuro Ponorogo ini diselenggarakan oleh tim pengabdi dari Program Kreativitas Mahasiswa Pengabdian Masyarakat (selanjutnya ditulis PKM-PM) dari Universitas PGRI Madiun. Rangkaian program ini disusun secara ilmiah, menyenangkan dan menarik sebagaimana tertulis dalam tabel 1.

Tabel 1. Jadwal Pelaksanaan Program Literasi Digital

\begin{tabular}{|c|c|c|}
\hline Kegiatan/Langkah & $\begin{array}{c}\text { Keterangan Kegiatan } \\
\text { Menetepkan lokasi kegiatan, } \\
\text { mengurus perizinan, dan } \\
\text { Pra-sosialisasi }\end{array}$ & $\begin{array}{c}\text { Minggu pertama Juni } \\
\text { mentukan jadwal tentatif } \\
\text { kegiatan. }\end{array}$ \\
\hline Sosialisasi program \\
literasi digital & $\begin{array}{c}\text { Melakukan sosialisasi dan } \\
\text { pengenalan program literasi } \\
\text { digital kepada anak-anak serta } \\
\text { penjelasan pentingnya literasi } \\
\text { digital bagi anak-anak di masa } \\
\text { kini. }\end{array}$ & Minggu kedua Juni 2021 \\
\hline
\end{tabular}


Program Literasi Digital bagi Anak-Anak Kampung Wonopuro, Dusun Sidowayah, Kabupaten Ponorogo Endang Sri Maruti, Binti Isticomah, Galuh Mei Yustiwa, Ulifa Khoiru, \& Nur Huda

\begin{tabular}{|c|c|c|}
\hline & $\begin{array}{c}\text { Pengayaan buku-buku bacaan } \\
\text { yang telah dicetak dari } \\
\text { Perpustakaan Digital Let's Read }\end{array}$ & Minggu kedua Juni 2021 \\
\hline & $\begin{array}{c}\text { Pengenalan aplikasi } \\
\text { Perpustakaan Digital Let's Read }\end{array}$ & Minggu ketiga Juni 2021 \\
\hline & $\begin{array}{l}\text { Pemilihan berbagai buku di } \\
\text { aplikasi Let's Read }\end{array}$ & Minggu ketiga Juni 2021 \\
\hline & $\begin{array}{c}\text { Membaca dan mengulas buku } \\
\text { yang dibaca di aplikasi Let's } \\
\text { Read }\end{array}$ & Minggu ketiga Juni 2021 \\
\hline Pascasosialisasi & $\begin{array}{c}\text { Refleksi dan rencana tindak } \\
\text { lanjut }\end{array}$ & $\begin{array}{l}\text { Minggu keempat Juni } \\
2021\end{array}$ \\
\hline
\end{tabular}

\section{Pelaksanaan}

\section{Pra-Sosialisasi Program Literasi Digital}

Pelaksanaan program sosialisasi aplikasi Let's Read dalam kegiatan literasi digital bagi anakanak Kampung Wonopuro Kabupaten Ponorogo sebelumnya didahului dengan tahapan persiapan atau pra-sosialisasi. Kegiatan awal ini dilaksanakan pada minggu pertama bulan Juni 2021 dengan penjelasan sebagai berikut.

\section{Penetapan Daerah Sasaran}

Langkah pertama yang dilakukan adalah menetapkan daerah sasaran, yaitu Kampung Wonopuro di Desa Sidoharjo, Kecamatan Jambon, Kabupaten Ponorogo. Daerah sasaran yang dipilih merupakan wilayah terisolir dimana untuk menuju wilayah tersebut hanya ada satu jalan yang berupa jalan setapak selebar 1-2 meter, itupun dengan kondisi jalan yang terjal, naik turun, dam berkelok-kelok karena berada di puncak gunung (Gambar 1). Akses jalan ini bisa ditempuh dengan sepeda motor, namun hanya orang tertentu yang dapat melalui jalannya, yakni orang yang benar-benar menguasai medan jalan. Selain itu, hanya bisa dengan berjalan kaki.

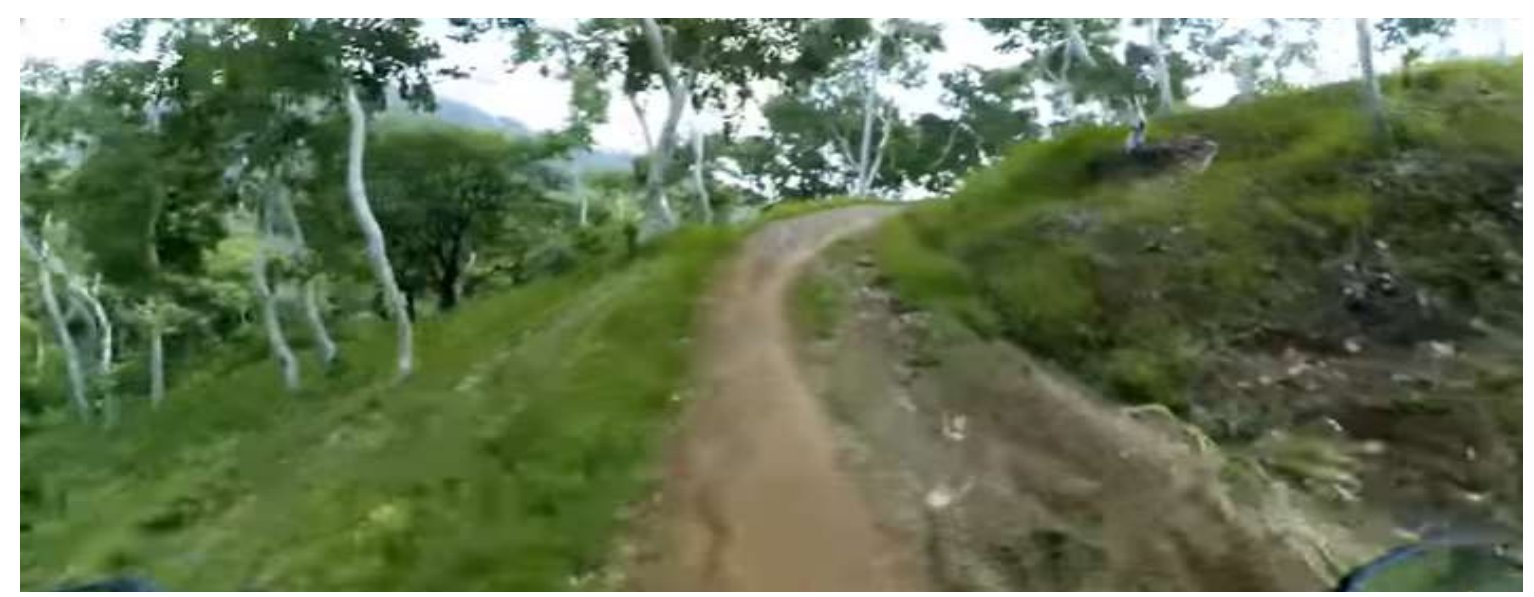

Gambar 1. Jalan menuju Kampung Wonopuro 
Wilayah ini sangat membutuhkan sentuhan tangan dari masyarakat luar khususnya para mahasiswa yang tergerak hatinya untuk membantu anak-anak usia sekolah dalam menghadapi pembelajaran jarak jauh di masa pandemi seperti ini. Melihat kondisi geografis Kampung Wonopuro tersebut, banyak permasalahan yang dihadapi masyarakat sekitar, terutama dalam bidang pendidikan di era pandemi Covid-19 seperti sekarang ini. Dalam kondisi normal sebelum pandemi, anak-anak harus berjalan kaki sejauh $5 \mathrm{~km}$ untuk sampai ke sekolah yang berada di bawah bukit untuk dapat mengenyam pendidikan dasar secara formal. Ketika pulang pun mereka kembali berjalan kaki selama kurang lebih 1 jam hingga sampai ke rumah. Setiap harinya untuk mendapatkan pendidikan mereka harus memakai banyak waktu di perjalanan.

Di kampung ini, didapati kebutuhan untuk memberikan bantuan peningkatan literasi digital bagi anak-anak dalam menyeimbangi perkembangan teknologi dalam dunia pendidikan di daerah terpencil guna meningkatkan potensi serta prestasi. Jumlah anak-anak usia sekolah di kampung Wonopuro berjumlah 23 anak, dengan rincian sepuluh siswa sedang mengenyam pendidikan di tingkat SMP, delapan siswa menempuh pendidikan Sekolah Dasar, serta lima lainnya tidak atau belum bersekolah. Tujuan literasi digital bagi anakanak desa terisolisir ini adalah untuk mengedukasi masyarakat dalam memanfaatkan teknologi dan komunikasi dengan menggunakan teknologi digital dan alat-alat komunikasi atau jaringan untuk menemukan, mengevaluasi, menggunakan, mengelola, dan membuat informasi secara bijak dan kreatif. Program ini ditujukan kepada anak-anak yang membutukan edukasi dan literasi guna meningkatkan keahlian dalam berteknologi.

\section{Izin dan Rencana Pelaksanaan Kegiatan}

Setelah menetapkan daerah sasaran, tim kemudian berkoordinasi dengan pihak yang berwenang untuk melaksanakan kegiatan di Kampung Wonopuro RT.11 RW.03 Dusun Sidowayah Desa Sidoharjo Kecamatan Jambon Kabupaten Ponorogo untuk melakukan edukasi pelatihan dalam program yang diberi nama Smart Educenter. Pihak yang ditemui adalah Kepala RT 11. Beliau sangat terbuka dan antusias dengan tawaran program, sehingga membolehkan dan memfasilitasi kegiatan untuk dapat dilakukan di Pondok Baca yang terletak di pusat RT (Gambar 2).

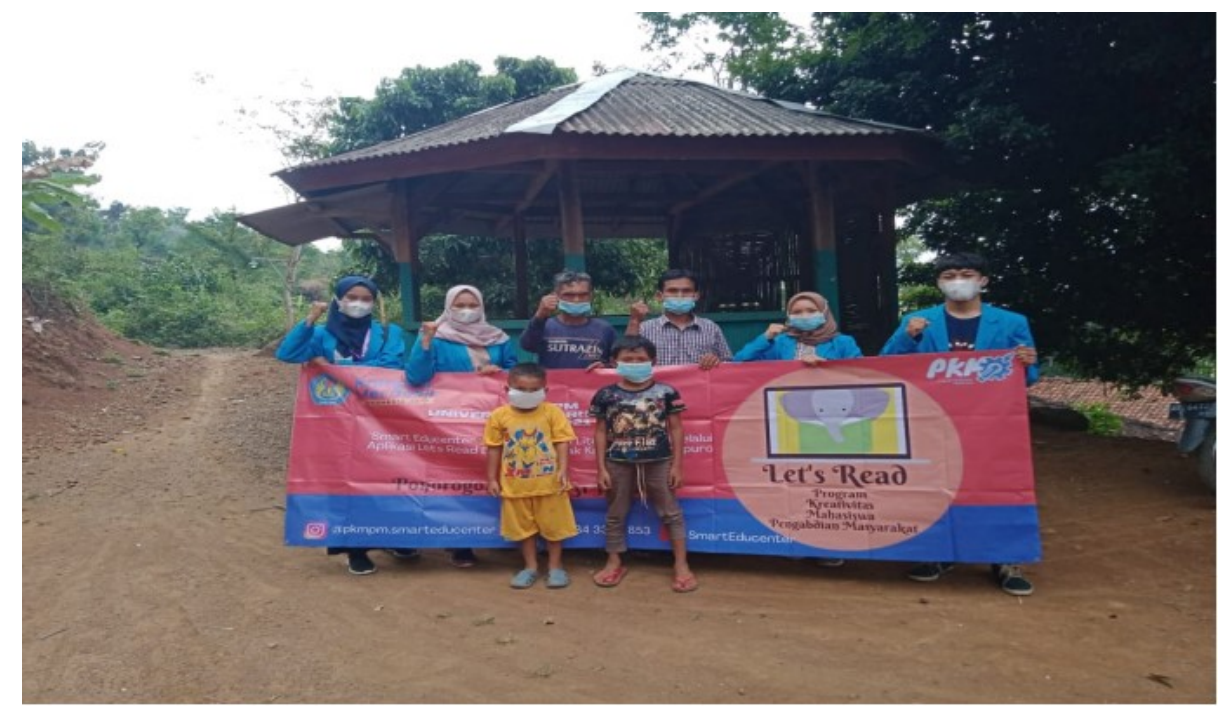

Gambar 2. Pondok Baca sebagai Lokasi Sosialisasi 
Setelah berkoordinasi dan mendapatkan izin, langkah selanjutnya yaitu menentukan hari, tanggal dan waktu untuk sosialisasi. Selain itu, tim PKM-PM juga membuat rancangan sistem program, meliputi pembagian tugas, menganalisis dan menentukan alat maupun media yang digunakan pada saat edukasi pelatihan literasi digital anak-anak tersebut.

\section{Sosialisasi Program Literasi Digital}

Pelaksanaan program sosialisasi aplikasi Let's Read dalam kegiatan literasi digital bagi anakanak Kampung Wonopuro Kabupaten Ponorogo dilaksanakan pada minggu kedua dan ketiga bulan Juni 2021 dengan penjelasan sebagai berikut.

\section{Pengenalan Literasi Digital}

Pada tahap ini dilakukan pengenalan program literasi digital serta penjelasan pentingnya literasi digital bagi anak-anak di masa kini. Setelah anak-anak berkumpul, kegiatan dimulai dengan bernyanyi dan berkenalan. Selanjutnya, setelah suasana hangat dan anak-anak siap menerima materi tentang literasi, tim PKM-PM menjelaskan beberapa kegiatan yang termasuk dalam literasi digital. Kegiatan itu bertujuan untuk membuat anak (1) lebih percaya diri, lancar dan paham dalam keterampilan membaca dan menulis; (2) tertarik pada buku-buku literasi, menikmati kegiatan membaca, mengevaluasi dan menilai bacaan yang dibaca; (3) mengetahui dan memahami berbagai jenis fiksi dan puisi; (4) memahami dan mengakrabi struktur dasar narasi; (5) memahami dan menggunakan berbagai teks nonfiksi; (6) menggunakan berbagai macam petunjuk baca (fonik, grafis, sintaksis, dan konteks) untuk memonitor dan mengoreksi kegiatan membaca secara mandiri; (7) merencanakan, menyusun draf, merevisi dan mengedit tulisan secara mandiri; (8) memiliki ketertarikan terhadap kata dan maknanya dan secara aktif mengembangkan kosakata; (9) memahami sistem bunyi dan ejaan dan menggunakannya untuk mengeja dan membaca secara akurat; dan (10) lancar dan terbiasa menulis tulisan tangan.

\section{Pengayaan buku-buku bacaan dari perpustakaan digital Let's Read}

Setelah anak-anak mendengarkan penjelasan tentang literasi digital dengan berbagai aktivitas yang menarik dan menyenangkan, kemudian anak-anak diberi beberapa buku bacaan. Buku-buku tersebut diperoleh oleh tim PKM-PM dengan cara mengunduh dari aplikasi Let's Read dan kemudian dicetak. Anak-anak diminta untuk membaca buku cetak tersebut secara bergantian dengan berbagai tema yang berbeda (Gambar 3). 


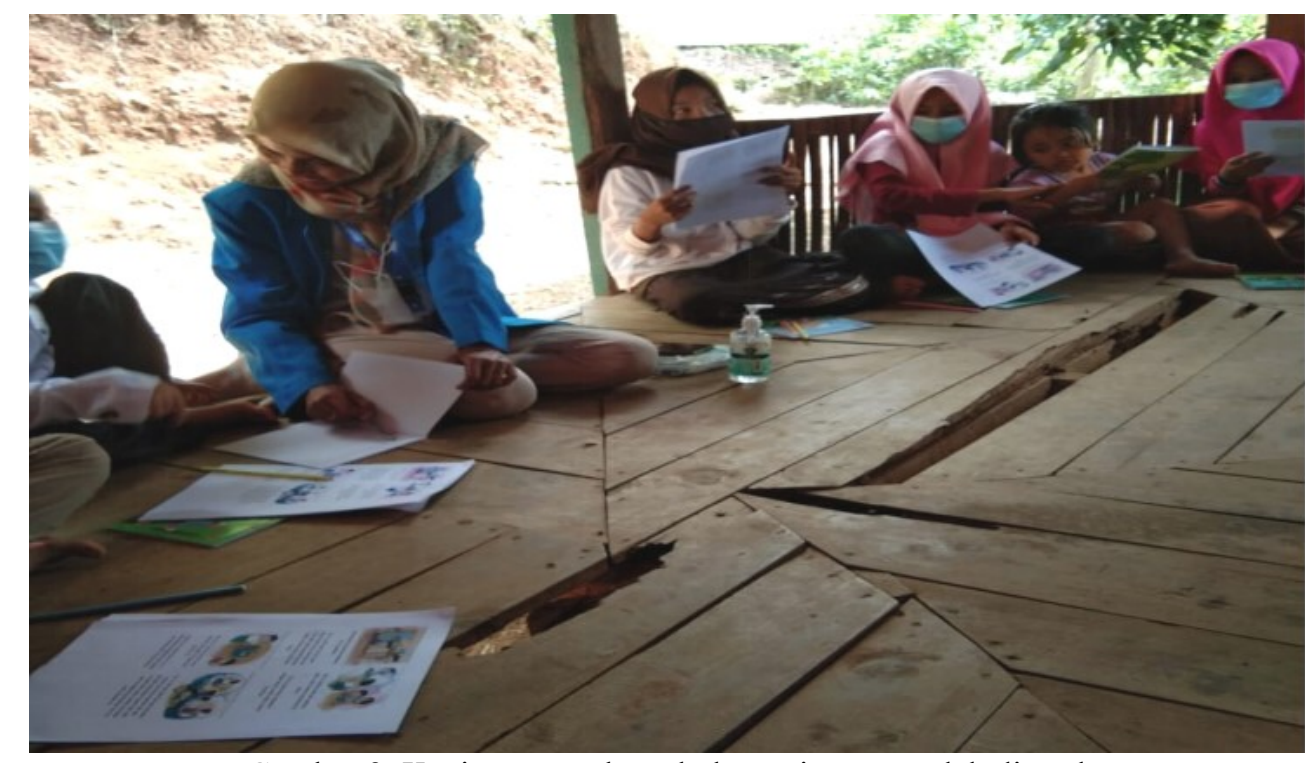

Gambar 3. Kegiatan membaca buku cerita yang telah dicetak

Ada beberapa tema cerita yang diberikan kepada anak-anak, mulai dari pengalaman pribadi yang menyenangkan, cerita tentang hewan peliharaan, hingga cerita terkait virus corona yang sedang melanda dunia saat ini. Secara bergantian, anak-anak membacakan cerita di depan anak-anak yang lain sambil menunjukkan gambar yang ada dalam buku cerita.

\section{Pengenalan aplikasi Perpustakaan Digital Let's Read}

Setelah mengenal buku cerita bergambar yang telah diunduh dan dicetak dari aplikasi Let's Read, kini giliran anak-anak dikenalkan langsung pada aplikasi ini di handphone masingmasing. Let's Read merupakan satu-satunya perpustakaan digital gratis Asia untuk anakanak, sehingga siapapun dapat mengakses bacaan berkualitas dari Let's Read Termasuk mereka yang tinggal di pelosok yang jauh dari akses perpustakaan fisik bahkan perpustakaan keliling. Meski dalam bentuk digital, semua koleksi buku di Let's Read sama seperti buku anak versi cetak, tetap bergambar dan berwarna. Didukung ilustrasi menarik membuat cerita yang ditampilkan menjadi "hidup". Hal ini akan membantu anak untuk memvisualisasikan jalan cerita, dan pastinya membuat anak-anak semakin tertarik dengan bukunya.

Ada banyak judul cerita dari berbagai negara di Asia yang bisa diterjemahkan ke dalam Bahasa Indonesia, juga ke dalam bahasa Ibu seperti bahasa Jawa, Minangkabau, Sunda dan Bali, sehingga anak-anak dari lintas Asia bisa mengakses cerita lintas budaya dengan bahasa lokal atau bahasa Ibu. Contohnya buku berjudul "Dina Kapisan Mlebu Sekolah?" (Hari Pertama Masuk Sekolah?) dalam bahasa Jawa. Hal ini tentu menjadi menarik bagi anak-anak, selain itu anak-anak menjadi lebih mudah mengerti isi ceritanya, karena menggunakan kata-kata yang sering diucapkan dalam percakapan sehari-hari di rumah. Dengan beragam kelebihan yang ada dalam aplikasi ini, tampak anak-anak kemudian dapat asyik dan menikmatinya.

\section{Pengoperasian aplikasi Let's Read}

Anak-anak diarahkan untuk mengunduh aplikasi Let's Read melalui perangkat android, baik telepon genggam atau tablet yang dibawa dari rumah. Meski akses transportasi cukup 
sulit, untuk jaringan internet dari beberapa operator seluler di daerah ini termasuk lancar dan terjangkau. Selain itu, ada juga penduduk yang menyediakan layanan koneksi internet nirkabel yang disewakan untuk masyarakat juga sangat lancar koneksi internetnya. Dengan didampingi tim, anak-anak mengunduh aplikasi dengan cepat (Gambar 4).

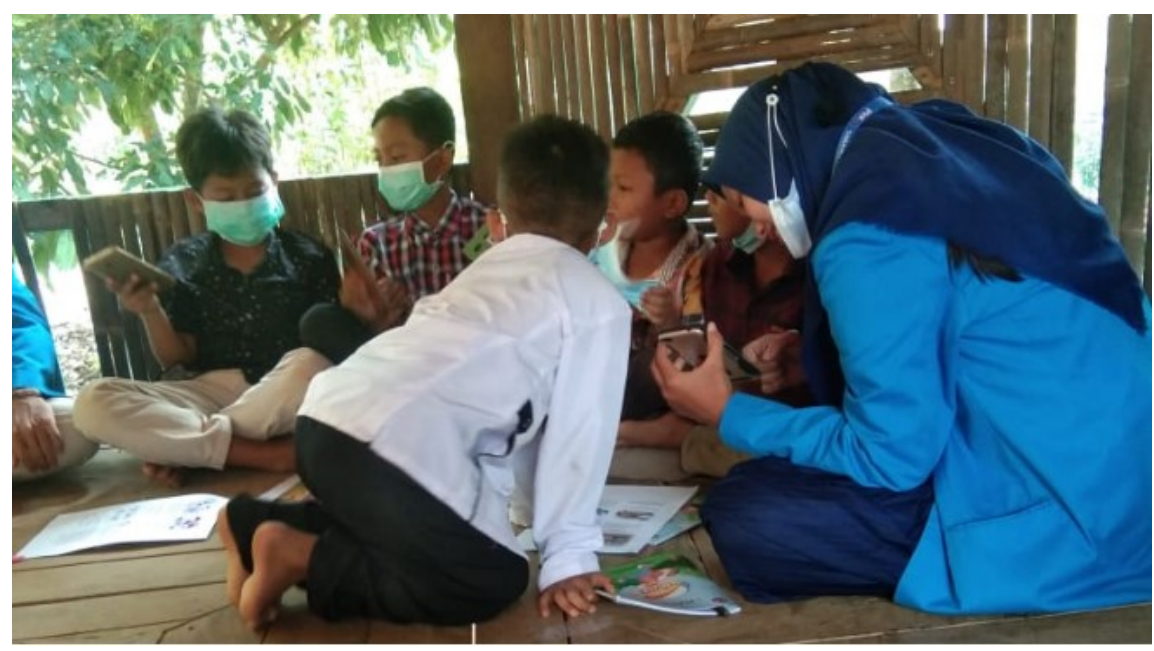

Gambar 4. Kegiatan Pengoperasian Aplikasi Let's Read

Setelah berhasil men-download dan meng-install, anak-anak dijelaskan tentang pengoperasiannya. Dalam aplikasi Let's Read, buku dikelompokkan menjadi 3 kelompok besar yakni berdasarkan: (1) bahasa, selain bahasa Inggris terdapat bahasa daerah seperti Jawa, Sunda, Minangkabau, Tagalog, dan lain-lain; (2) tingkat kesulitan, buku yang disajikan disesuaikan dengan kemampuan membaca anak, bukan usia anak, mulai tingkat kesulitan 1 sampai 5, di mana semakin tinggi tingkat kesulitannya, kosakatanya akan semakin bertambah; (3) label buku anak, terdapat buku-buku dengan tema pahlawan, sains, critical thinking, petualangan, hewan, seni dan musik, pemecahan masalah, nonfiksi, alam, anak perempuan hebat, kesehatan, lucu, cerita rakyat, komunitas, serta keluarga dan persahabatan. Anak-anak pun disuruh untuk mencari bacaan yang sesuai dengan minat mereka. Setelah menemukan judul bacaan yang sesuai, anak-anak kemudian membaca cerita secara bergantian. Anak-anak diminta membuka, memilih, dan membaca buku bacaan dalam aplikasi, serta menceritakan kembali di depan teman-teman yang lain (Gambar 5).

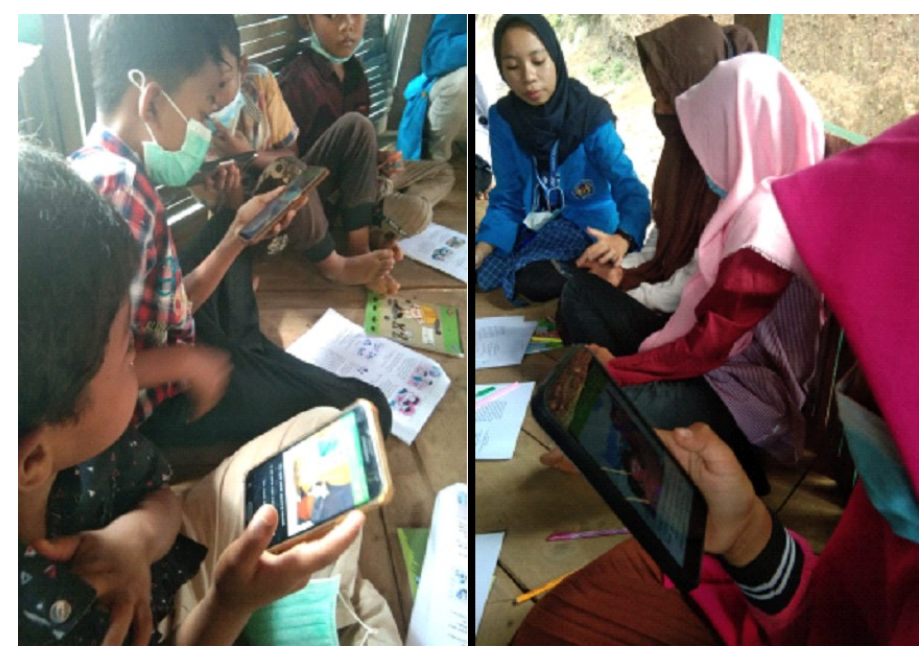

Gambar 5. Anak-anak asyik dengan Aplikasi Let's Read 


\section{Pasca-Sosialisasi Program Literasi Digital}

Tahap akhir dari kegiatan ini adalah tahap refleksi dan tindak lanjut. Anak-anak diminta untuk menceritakan pengalaman mereka setelah membaca dengan manual maupun dengan aplikasi Let's Read. Anak-anak bergantian menceritakan pengalaman mereka dalam membaca berbagai cerita dengan berbagai macam tema yang sangat menarik dan menyenangkan (Gambar 6).

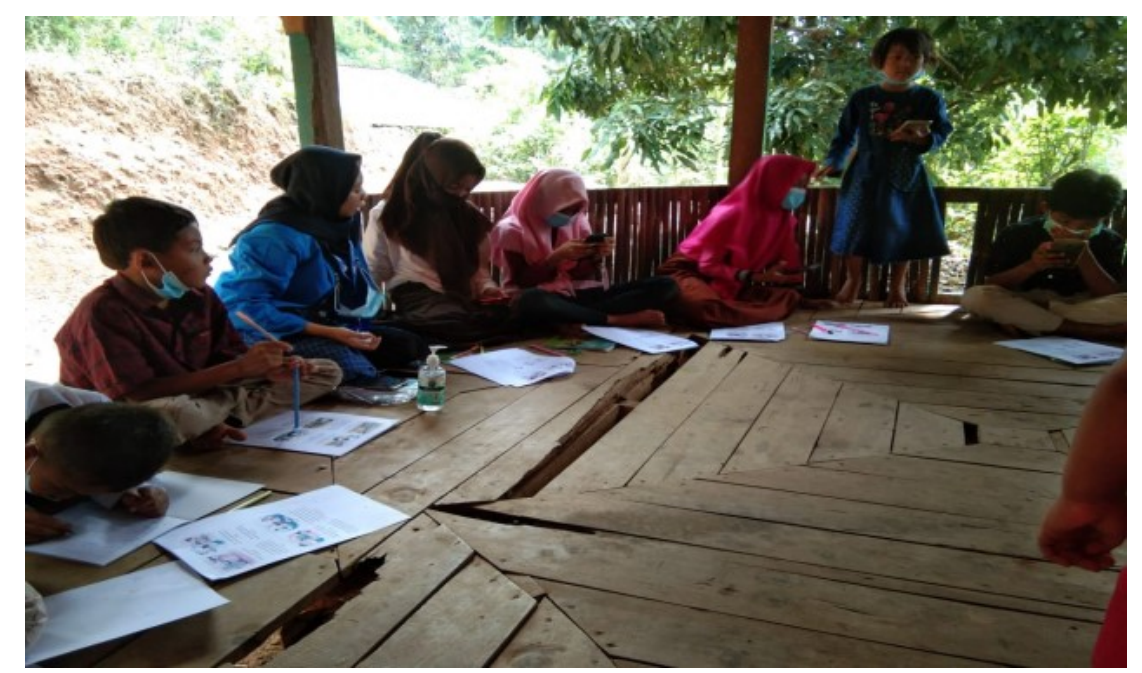

Gambar 6. Anak-anak bergantian merefleksikan pengalaman membaca melalui Aplikasi Let's Read

Sebagai sebuah hasil dari program pengabdian masyarakat, kegiatan membaca melalui aplikasi Let's Play ini diharapkan dapat berlangsung terus dan tetap dimonitor oleh tim PKM-PM. Salah satu langkah yang dilakukan untuk memastikan keberlanjutan program ini adalah dengan membentuk grup perpesanan WhatsApp (WAG). Dalam WAG ini, semua kontak anak-anak yang terlibat dalam kegiatan dimasukkan sebagai anggota (Gambar 7).
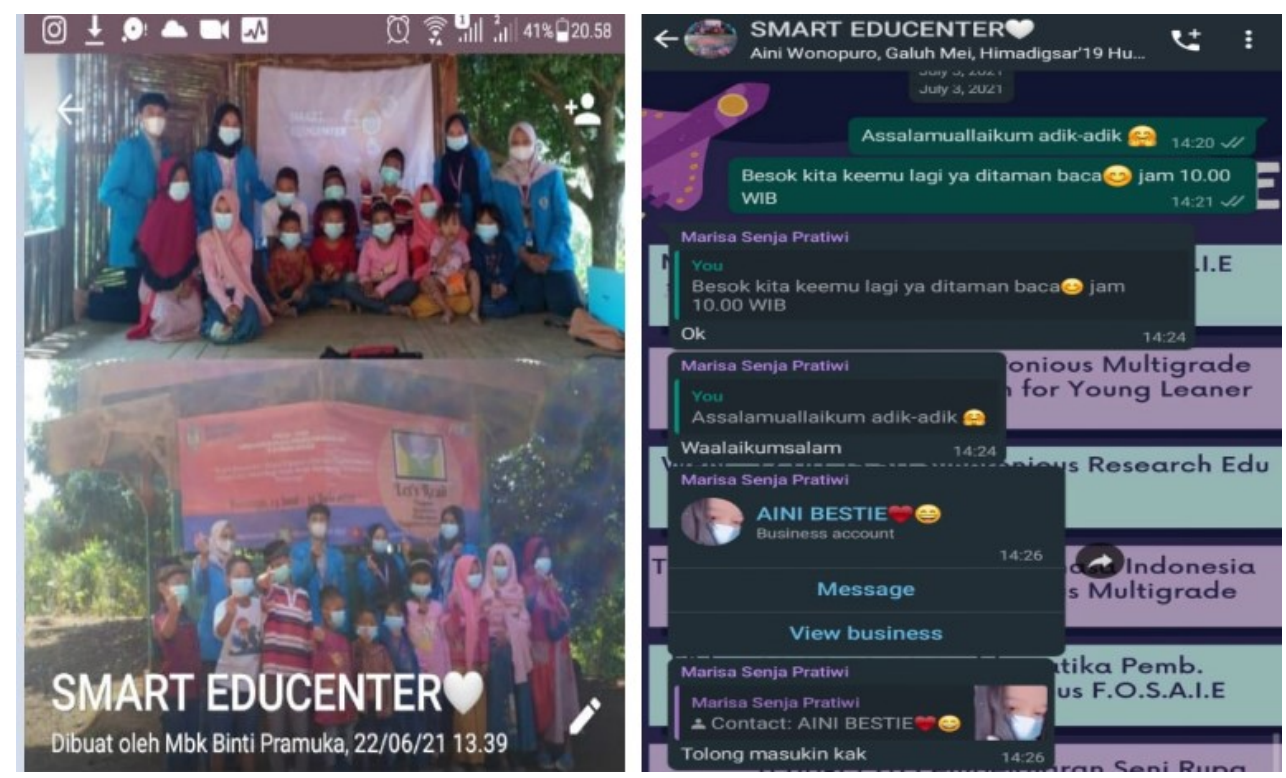

Gambar 7. Pembuatan Grup Whatsapp sebagai media tindak lanjut kegiatan

Dalam grup ini anak-anak bisa menanyakan segala sesuatu terkait dengan kegiatan literasi khususnya literasi digital yaitu kegiatan membaca pada aplikasi Let's Read. Melalui grup ini juga, tim PKM-PM dapat memberikan instruksi kepada anak-anak untuk secara bertahap dan bergantian membaca cerita dalam aplikasi Let's Read. Anak-anak disuruh merekam video atau 
dalam bentuk voice note (pesan suara) agar tim juga bisa mengoreksi kelancaran membaca maupun intonasi dalam membacakan teks cerita. Tim PKM-PM juga bisa memberikan umpan balik serta masukan untuk dapat tetap meningkatkan kegiatan literasi anak-anak, khususnya di Kampung Wonopuro.

\section{Kesimpulan}

Berdasarkan paparan kegiatan pengabdian kepada masyarakat di atas, dapat disimpulkan bahwa program ini dapat meningkatkan literasi digital bagi anak-anak Kampung Wonopuro. Hasil ini didapat dari 12 anak yang ikut program, 10 di antaranya mengatakan bahwa melalui kegiatan ini, keinginan dan kebiasaan membaca kembali tumbuh dan meningkat, apalagi di masa pandemi sekarang. Pada akhirnya, dengan mengikuti sosialisasi penggunaan aplikasi Let's Read, pengetahuan anak-anak secara umum, ataupun dalam konteks literasi digital, menjadi semakin bertambah.

\section{Pernyataan}

Ucapan terima kasih dihaturkan kepada Direktur Pembelajaran dan Kemahasiswaan Kementerian Pendidikan dan Kebudayaan Republik Indonesia yang telah memberi kesempatan dan pendanaan untuk kegiatan PKM-PM ini, Rektor Universitas PGRI Madiun yang telah memberi dukungan untuk menyelesaikan penulisan artikel ilmiah ini, Dosen Pendamping yang telah membimbing dalam proses penulisan artikel ilmiah hasil pengabdian masyarakat ini, dan anak-anak serta orang tua hebat Kampung Wonopuro, Kabupaten Ponorogo, juga kepada semua pihak yang telah berkonstribusi pada kegiatan ini yang tidak bisa disebutkan satu per satu.

\section{Referensi}

Abidin, Y. (2015). Pembelajaran Multiliterasi: Sebuah Jawaban atas Tantangan Pendidikan Abad Ke-21 dalam konteks Keindonesiaan. Bandung: PT Refika Aditama.

Ermerawati, A. B. (2019). The Application of Let's Read! in Extensive Reading Class: Integrating MALL and Task-Based Learning. Elementary School Forum (Mimbar Sekolah Dasar), 6(3), 317-329. http://dx.doi.org/10.17509/mimbar-sd.v6i3.20870

Fitriawan, F., Rohmatulloh, D., Asfahani, A., \& Ulfa, R. (2020). Pemberdayaan Ekonomi Pemuda Melalui Budidaya Jamur Tiram di Dusun Sidowayah, Kecamatan Jambon, Kabupaten Ponorogo. Amalee: Indonesian Journal of Community Research and Engagement, 1(1), 47-58. https://doi.org/10.37680/amalee.v1i01.187

Harras, K. A. (2011). Mengembangkan Potensi Anak melalui Program Literasi Keluarga. Artikulasi, 144.

Heath, S. B. (2011). Language Socialization in Art and Science. In The Handbook of Language Socialization (eds A. Duranti, E. Ochs and B.B. Schieffelin). https://doi.org/10.1002/9781444342901.ch18

Hull, G.A. and Hernandez, G. (2008). Literacy. In The Handbook of Educational Linguistics (eds B. Spolsky and F.M. Hult). https://doi.org/10.1002/9780470694138.ch23 
Putri, F. (2021). Let 's Read! Ayo Membaca Menyenangkan dengan Anak. Mencintai Membaca Sejak Dini - My Setelah Menjadi Ibu .... https:/faradiladputri.com/lets-read-ayomembaca-menyenangkan-dengan-anak/

Samsiyah, N. (2019). Pengembangan Literasi Baca Audio Visual Berbasis Kearifan Lokal di Kabupaten Madiun. Prosiding Seminar Nasional "Penguatan Muatan Lokal Bahasa Dan Sastra Daerah Sebagai Fondasi Pendidikan Karakter Generasi Milenial, 191-198.

Samsiyah, N., Suharto, V. T., \& Maruti, E. S. (2019). Literacy Literature Learning with Let's Read Applications in The Pandemic Era. JURNAL HANDAYANI PGSD FIP UNIMED, 11(1), 57-62. https://doi.org/10.24114/jh.v11i1.18666

Street, B. V. (1993). Cross-cultural approaches to literacy (Issue 23). Cambridge University Press. 